\title{
EDITORIAL/EDITORIAL
}

\section{Mervyn Susser}

Mauricio Gomes Pereiral

Mervyn Susser, Professor Emeritus at Columbia University, School of Public Health, passed away on August 14, 2014, in his residence in New York, at the age of 92. Susser was a great friend of the Brazilians, having collaborated for many years as a member of the Editorial Board of the Brazilian Journal of Epidemiology. He had great influence on the field of Epidemiology during the second half of the $20^{\text {th }}$ century, and also in the beginning of the $21^{\text {st }}$, especially with respect to the methodological and philosophycal aspects of epidemiology plus the relationship between health and society.

\section{EARLY YEARS, EDUCATION, AND RESEARCH}

Susser was born in South Africa on September 26, 1921, where he graduated in Medicine along with his wife, Zena Stein, his lifelong companion. They both worked at health care centers in the rural areas of the country, which had great influence on their reflections concerning the social determinants of a disease and on their active stand towards human rights.

Due to political difficulties of the Apartheid, the couple emigrated to England in 1956, where Susser held a position in the Department of Preventive and Social Medicine at the University of Manchester. In 1966, he moved to the United States and became full professor and Head of Department at the Columbia University, School of Public Health, in New York. In 1978, he founded the Sergievsky Center at Columbia University, a unit for the investigation of neurological and psychiatric problems and developmental epidemiology. He retired in 1990, but remained linked to the University and to projects from numerous countries, in particular those dedicated to AIDS in Africa.

Susser and Stein always worked together and played a significant role in all activities they undertook. Until recently, every year the couple used to spend a few months in South Africa, involved in activities for the fight against AIDS in that country, which meant research, education and getting involved in organizing health care for the population. 


\section{PUBLICATIONS}

Susser published hundreds of articles, but the comments here are centered on his books. The first one was Sociology in Medicine, in 1962, written with the anthropologist William Watson ${ }^{1}$. In this book there is the basis for his understanding of social sciences and health.

In the next decade, Susser put together a series of lectures which he had given at the University of Columbia in a book titled Casual Thinking in the Health Sciences ${ }^{2}$. It was published in 1973 and became his best-known work.

In 1975, he published the reports of an observational study concerning the famine in Holland during the World War II and its repercussions over health, Famine and Human Development ${ }^{3}$. Some years later, he published the book Diet in Pregnancy which dealt with the Prenatal Project, a randomized study regarding nutritional supplementation to pregnant women ${ }^{4}$. Finally, in 2009, he published Eras in Epidemiology: the Evolution of Ideas ${ }^{5}$.

\section{APPRECIATION FOR MERVYN SUSSER AND ZENA STEIN}

During my stay as a PhD student at Columbia, 1974 - 1977, I had Dr. Susser as my advisor. Rather, he was my principal advisor, since I was actually advised by both Susser and Stein. Always by appointment, as it is the custom in those parts of the world, I used to meet them out regularly. Some months after my arrival in New York, and I was lucky enough to see the Department of Epidemiology move to the first floor of the 31-storey building where I lived, in the Medical Center of Columbia, more precisely on Haven Avenue, an extension of $168^{\text {th }}$ West Street, Uptown Manhattan. I began to stay at that department full-time, so it was easier for me to become involved with the projects that were being carried out there. I was a research assistant for one of the studies, the Prenatal Project, a randomized experiment of preventive nature, conducted at Harlem Hospital ${ }^{4}$. While I worked on this project I was really introduced to scientific methodology. My thesis, advised by Susser and Stein, was taken from the content of that study. I also became involved in teaching the students from the Columbia School of Medicine and provided peer reviews for scholarly articles. At the time, I became interested in studying the logic of scientific communication, guided by Susser, who later became an editor for the American Journal of Public Health. This period cemented my knowledge and greatly helped me when I later wrote the book Artigos Científicos: como Redigir, Publicar e Avaliar ${ }^{6}$.

Susser and Stein came to Brazil many times; one of them they went to Bahia, in 1994, as the main guests at the Brazilian Congress of Epidemiology. Some years earlier, they came to Brasília. Susser gave a seminar at University of Brasília. For me, the contact with the couple led to a moment of reflection and change of ideas. The couple saw the difficulties the university was facing due to the lack of specialized 
staff — there were only two professors of Epidemiology, including me - and scarce resources, demand for classes, meetings and little administrative support. I asked Susser what he would do if he were in my position. This was his reply: How about a book? This was the beginning of Epidemiologia: Teoria e Prática, which I published years later ${ }^{7}$.

In the decades that followed the conclusion of my graduate studies, I often returned to my North American Alma Mater, the University of Columbia. The friendship with the couple was facilitated by their habit of gathering current and previous students and collaborators at their house. Every time I visited the city, I would get in touch with them, go to the University and get invited to their residence on the weekend.

Susser and Stein remained connected to South Africa. Numerous South African students were trained by them at the University. The couple accepted them because of their studies, but also due to the fact that many were being politically persecuted. Not only South Africans, but also students from other countries were benefitted. I remember a young Chilean, Elie Valencia, whom I met while he was staying at the residence of the couple since he had arrived in the United States. I spoke to him in Spanish. He was politically persecuted and did not seem to be much older than 20 . Susser told me that Elie did not speak a word in English. I asked him how they communicated. Susser replied, in his friendly and paternal tone, that they got along great. "We don't say a word, but laugh quite a lot with each other," he added. Elie lived there for a long time. Years later, during a lunch at Susser and Stein's, I saw Elie again and he seemed quite at ease: he spoke English fluently and had his wife and baby with him. The way they interacted, I deduced he had become a member of the family.

I will tell you two other stories about the couple Susser and Stein in New York. The first was in May 2001. When he turned 80 years old, a symposium at the University of Columbia was dedicated in honor of Mervyn Susser. At the end of the symposium, which lasted an entire day, a letter sent from South Africa was read.

Dear Zena and Mervyn

As someone who became an octogenarian three years ago, I have great pleasure in saying 'Welcome to the Club'. Over the years, especially when we were in prison, we managed to get trickles of information about you. It was always heartening to know that, albeit under different circumstances and many miles from home, your commitments and active contribution to struggle for democracy remained undiminished. Although we are divided by a great distance today, please know that our thoughts and best wishes are with you, and with all the friends who are joining you in the celebration.

Hearty congratulations!

Nelson Mandela

On the day following the symposium, there was a great celebration at Hastings-on-Hudson, where Susser and Stein's residence was located, on the outskirts of New York City. The master of ceremony was Ezra Susser, the couple's son and full professor of Epidemiology at Columbia. During the event, Marvin Susser's numerous former students and collaborators 
gave testimonials regarding their experience with the Master. The ceremony took up the entire afternoon.

The second story concerns the last time I was with the couple, in 2013, at their beautiful and warm home on the banks of the Hudson River. Stein, Susser, my wife, Cleire and I had lunch together. We had some white wine. They told me details about their preparation for the book Eras in Epidemiology $y^{5}$. After lunch, we walked along the vast property for more than one hour, it was covered by exuberant and well-cared vegetation. It was a pleasant autumn day. We walked in pairs along the trails. Susser and I talked and just behind us, Stein and Cleire. He was cheerful, agile, and without any difficulty pushed away enormous, heavy tree branches which had fallen along the path after the last rainfall. He seemed to be in great shape. At that moment I thought we would still have Mervyn around for a long time. The news of his death was a surprise. He lived a full and productive live until the end. Zena continues to be healthy, carrying on the fruitful work of the couple. Family members and numerous friends will miss Mervyn Susser forever.

\section{REFERENCES}

1. Susser M, Watson W. Sociology in Medicine. London: Oxford University Press; 1962.

2. Susser M. Causal Thinking in the Health Sciences: Concepts and Strategies in Epidemiology. New York: Oxford University Press; 1973.

3. Stein Z, Susser M, Saenger G, Marolla F. Famine and Human Development: the Dutch Hunger Winter of 1944-45. New York: Oxford University Press; 1975.
4. Rush D, Stein Z, Susser M. Diet in Pregnancy: a Randomized Controlled Trial of Nutritional Supplements. Birth Defects Orig Artic Ser 1980; 16(3): i-xxvi, 1-197.

5. Susser M, Stein Z. Eras in Epidemiology: the Evolution of Ideas. New York: Oxford University Press; 2009.

6. Pereira MG. Artigos Científicos: como Redigir, Publicare Avaliar. Rio de Janeiro: Editora Guanabara-Koogan, 2011.

7. Pereira MG. Epidemiologia: Teoria e Prática. Rio de Janeiro: Editora Guanabara-Koogan, 1995. 